Sharif University of Technology
Scientia Iranica
Transactions E: Industrial Engineering
SCIENTIA
I RAN I C A

\title{
Application of fuzzy group analytic hierarchy process in partner selection of international joint venture projects
}

\author{
S. Kimiagari ${ }^{\mathrm{a}, \mathrm{b}, *}$, S. Keivanpour ${ }^{\mathrm{a}, \mathrm{c}}$, F. Jolai ${ }^{\mathrm{d}}$ and M. Moazami ${ }^{\mathrm{e}}$ \\ a. Interuniversity Research Centre on Enterprise Networks, Logistics, and Transportation (CIRRELT), Montreal, QC, Canada. \\ b. Department of Management, Laval Business School (FSA), Laval University, Quebec city, Qc, Canada. \\ c. Department of Mechanical Engineering, Faculty of Science and Engineering, Laval University, Quebec City, Qc, Canada. \\ d. Department of Industrial Engineering, College of Engineering, University of Tehran, Tehran, Iran. \\ e. Petroleum University of Technology, Oil Ministry, Tehran, Iran.
}

Received 22 August 2014; received in revised form 22 September 2015; accepted 4 January 2016

\section{KEYWORDS \\ International joint ventures; \\ Partner selection; \\ Fuzzy group AHP; \\ MCDM; \\ Petrochemical \\ company.}

\begin{abstract}
Partner selection is gradually recognized as an essential factor in gaining success in a cooperative settings. In this paper, a novel approach based on fuzzy AHP group decision-making for partner selection of joint venture projects is proposed. In this approach, first, the influential factors for selection of appropriate partners based on literature review and interviews with experts are identified. Then, using a method considering the risk, knowledge, and educational background of decision-makers, the impact of decision-makers is calculated. Pairwise comparison matrices are performed, and the weights of criteria are calculated based on two methods (multiplicative and additive). Then, the calculated weights of criteria and the potential partners have been ranked via an efficient ranking index. Finally, the application of this methodology to a real case study in National Iranian Petrochemical Company (NPC) is conducted. The contribution of this study is developing a fresh systematic approach for partner selection of international joint ventures and application in a real-life case study to present an operational guideline to the petrochemical industries. The results of this study reveal that the equipment of the partner, its financial capacity, trusts and management skills are the most important criteria for establishing the durable partners in the international joint venture of NPC.
\end{abstract}

(C) 2016 Sharif University of Technology. All rights reserved.

\section{Introduction}

Companies are continually motivated to gain access to new markets and new supply sources, capitalize on technology, use assets better, and become more profitable. Establishing joint ventures and strategic alliances are commonly used by companies to exploit numerous advantages, such as increased leverage, risk sharing, opportunities for growth, and greater responsiveness [1]. The international joint venture is a

*. Corresponding author.

E-mail addresses: Salman.Kimiagari@cirrelt.ca (S. Kimiagari); Samira.Keivanpour@cirrelt.ca (S. Keivanpour); fjolai@ut.ac.ir (F. Jolai) major arrangement of business and is extensively used by multinational corporations. The establishment of international joint ventures constructs mutual synergy. Partners from developing countries benefit from the technological know-how, management skills, and investment provided by the overseas partners. Moreover, multinational corporations could benefit from the host countries' business context and local companies to moderate risks and augment returns [2,3]. Partner selection is one of the essential decisions that a company makes after selecting the joint venture as an entry mode [4]. Considering growing standing of joint ventures as an internationalization mode, studying partnering strategies and influential factors in the performance of these ventures is critical [5]. Few studies 
addressed a systematic approach for partner selection of joint ventures. Aydogan and Koksal [6] proposed an Analytical Network Process to assess the priorities of the determined risk factors in partner selection for international construction joint ventures. Hajidimitriou and Georgiou [7] demonstrated the goal programming approach to evaluating potential candidates and selection of the optimal partner for international joint ventures. In the real business situation, many components involved in partner selection are intangible in nature. Thus, they are challenging to measure quantitatively. Essentially, when measuring what is considered as an intangible parameter, most experts offer linguistic evaluations instead of precise numerical values to indicate their views $[8,9]$. Moreover, there are different experts involved in the decision-making process. Hence, there is a gap in literature to develop a systematic approach for partner selection of international joint venture considering the uncertainties of the parameters and different expertise involved in a decision-making procedure. In this paper, partner selection is molded using Fuzzy AHP group decision-making. The purpose of the analysis is to offer guiding principles to decision-makers to generate and sustain a valuable balance among partner selection influential factors. The core advantage of fuzzy AHP method is the comparative simplicity of handling multiple criteria $[10,11]$. Furthermore, it provides a systematic tool for computing weights of criteria through pairwise comparisons [12,13]. Currently, the National Petrochemical Company (NPC) is the second main producer and exporter of petrochemicals in the Middle East. Establishment joint venture in petrochemical facilities and service companies with right foreign companies is considered as policy and qualitative objective for this company to lead to stability and sustainable development (NPC website [14]). Moreover, it can be seen as a tool needed to achieve competitive advantages to attain political and commercial objectives. In this regard, selection of the appropriate partner or partners is a crucial challenge for NPC. The proposed methodology allows the comparison of potential partners in the perspective of NPC to provide long-term and sustainable outcomes of collaboration. The organization of this paper is as follows. First, the literature of international joint ventures and the partner selection methods are studied. Then, the Fuzzy group multi-criteria decision-making approach for JVs partner selection is introduced. Then, the application of the proposed method in a real case study (NPC JVs partner selection) is provided.

\section{International joint venture and performance measurement factors}

The classic dentition of Joint Venture (JV) based on OECD (Organisation for Economic Cooperation and
Development) is the joint operation of two or more firms in order of the following areas: buying or selling, development or production operation, research, and development or engineering, and construction [15]. The literature of JVs consists of theoretical basis and performance measurement. In Table 1, we provide the main areas of theoretical directions and the performance measurement literate. According to Child and Yan [16], the performance of international joint ventures carries on being a challenging issue both for practitioners and researchers. According to Demirbag and Mirza [17], there is not a unified theory for performance measurement of the international joint ventures, but the literature of success factors of these corporations could enlighten the framework of the performance measurement elements. Measuring JV performance should be studied with outstanding attention, considering the objectives of forming the venture [18]. For example, according to Beamish \& Delios [19], if the JV is established for technology transfer, the performance should be measured based on this objective; however, the efficiency of this collaboration may be poor in the other areas like survival or duration. Hence, in this study, in order to achieve an efficient basis for partner selection of IJVs, in addition to the framework provided by literate, we derived the model elements from interviewing and discussing with the industrial experts while bearing in mind the objectives of the JVs in the relevant industrial context.

\section{Fuzzy decision-making approach in partner selection}

According to Bellman and Zadeh [51], much of decisionmaking in a real world situation is in the situations in which the goals, constraints, or the possible actions are not known precisely. They differentiate between randomness and fuzziness. Based on these authors, fuzziness needs to address the classes in which there may be grades of intermediate membership between full membership and non-membership. This approach used widely in recent literature considering the capability of fuzzy set theory in decision-making with uncertainties. Multi-criteria decision-making has been extensively taken into account considering the influence of different attributes in partner selection literature. Moreover, with respect to the subjective nature of qualitative factors or vagueness in decision maker's preferences, the fuzzy approach is an appropriate tool for dealing with such problems. Ding and Liang [52] used fuzzy multiple criteria decision-making in partner selection of strategic shipping alliances. They applied graded mean integration and the entropy weighting method for computing integrated weights and ideal and anti-ideal solutions for alternative priority ranking. Ding [53] proposed fuzzy MCDM in order to select an appropri- 
Table 1. The literature of JVs (theoretical basis and performance measurement).

\begin{tabular}{|c|c|c|}
\hline Direction of research & Perspectives & Related studies \\
\hline \multirow{6}{*}{ Theoretical basis } & The transaction costs approach & {$[20,21,22,23]$} \\
\hline & The internationalization approach & {$[22,24]$} \\
\hline & The competitive strategy approach/strategic behaviour & {$[25,26,27]$} \\
\hline & Organizational knowledge and learning approach & {$[28,29,30,31]$} \\
\hline & Resource dependence approach & {$[32,33,34]$} \\
\hline & Bargaining power & {$[35,36]$} \\
\hline \multirow{25}{*}{ Performance of JVS } & Objective of forming JVs & \multirow{2}{*}[18,19]{} \\
\hline & Technology transfer & \\
\hline & Knowledge transferring & {$[37]$} \\
\hline & Local stability & \multirow{2}{*}[38]{} \\
\hline & Competitive advantages & \\
\hline & Partner-related factors & \multirow{4}{*}[17]{} \\
\hline & Sociocultural distance among partners & \\
\hline & Size of partner & \\
\hline & Government or private sectors & \\
\hline & Joint venture-related factors & \multirow{6}{*}[39-41]{} \\
\hline & Ownership and control & \\
\hline & Control & \\
\hline & Size & \\
\hline & Characteristics of products and services & \\
\hline & $\mathrm{R} \& \mathrm{D}$ & \\
\hline & Organizational and management factors & \multirow{5}{*}{$\begin{array}{c}\text { Conflict }[42], \\
\text { Behavioural factors } \\
\text { and trust }[43,44,45], \\
\text { Commitment } \\
{[46,47,48 \text { : cited in } 41]}\end{array}$} \\
\hline & Conflicts & \\
\hline & Behavioural factors & \\
\hline & Trust & \\
\hline & Commitment & \\
\hline & External factors & \multirow{5}{*}[49,50]{} \\
\hline & Influence of a host country & \\
\hline & Government's policies & \\
\hline & Legal structure & \\
\hline & Market structure & \\
\hline
\end{tabular}

ate strategic partner for container shipping company. Liou et al. [54] developed a methodology based on the joint application of ANP and fuzzy set theory in order to select a suitable strategic alliance in the airline industry. Ma and Wang [55] introduced a multiattribute group decision-making method for partner selection of logistics alliances. Yong [56] also developed an AHP structure with DEA for partner selection of strategic alliances. We have collected several studies in recent years which addressed partner selection with the fuzzy approach (Table 2). Fuzzy AHP (e.g. [57,58]), Fuzzy ANP (e.g. [59]), and Fuzzy-QFD (e.g. [60]) are the main approaches used in these works. The majority of the works focused on the supplier selection subject and the number of applications in the real case study are few. Considering the partner selection in international joint ventures in a case study application, this study tries to fill this gap in the literature.

\section{Fuzzy AHP group decision-making approach for IJVs partner selection}

In this section, we proposed a novel methodology with a combination of different approaches for partner selection of IJVs.

\subsection{Step 1: Establishing expert panel for group decision making and evaluation of the weight of experts}

For the group decision-making, we need a panel of experts, specialists, or authorities. Hence, it is essential to select the appropriate people in the panel in order to 
Table 2. Partner selection with fuzzy approach.

\begin{tabular}{|c|c|c|c|c|}
\hline No & Reference & Approach & Application & Case study \\
\hline 1 & {$[57]$} & $\begin{array}{l}\text { Fuzzy preference } \\
\text { programming based on } \\
\text { fuzzy analytical approach }\end{array}$ & $\begin{array}{l}\text { Partnership selection in formation } \\
\text { of virtual enterprises }\end{array}$ & Numerical example \\
\hline 2 & {$[58]$} & $\begin{array}{l}\text { Fuzzy Analytic Hierarchy } \\
\text { Process (FAHP) model, which } \\
\text { incorporates the benefits, } \\
\text { opportunities, costs and risks }\end{array}$ & Supplier selection & $\begin{array}{l}\text { TFT-LCD manufacturers } \\
\text { in Taiwan }\end{array}$ \\
\hline 3 & {$[59]$} & $\begin{array}{l}\text { Analytic Network Process (ANP) } \\
\text { and the Technique for Order } \\
\text { Performance by Similarity to } \\
\text { Ideal Solution (TOPSIS) methods }\end{array}$ & Long-term supplier selection & $\begin{array}{l}\text { Telecommunication company } \\
\text { in the GSM sector in Turkey }\end{array}$ \\
\hline 4 & {$[60]$} & Fuzzy-QFD approach & Supplier selection process & \\
\hline 5 & [61] & $\begin{array}{l}\text { Fuzzy Multiple Criteria } \\
\text { Decision-Making (MCDM) }\end{array}$ & Vendor selection & Empirical example \\
\hline 6 & {$[62]$} & $\begin{array}{l}\text { Fuzzy-rule-based jointly } \\
\text { with a fuzzy relationship } \\
\text { hierarchy }\end{array}$ & $\begin{array}{l}\text { Strategic supply chain } \\
\text { alliance under limited } \\
\text { evaluation resources }\end{array}$ & $\begin{array}{l}\text { An illustrative example of } \\
\text { a personal computer company }\end{array}$ \\
\hline 7 & {$[63]$} & $\begin{array}{l}\text { Fuzzy Preference } \\
\text { Programming (FPP) } \\
\text { method }\end{array}$ & $\begin{array}{l}\text { Supplier selection in } \\
\text { electronic marketplaces } \\
\text { company }\end{array}$ & $\begin{array}{l}\text { Example of a hypothetical } \\
\text { metal manufacturing }\end{array}$ \\
\hline 8 & [64] & $\begin{array}{l}\text { Fuzzy analytical approach } \\
\text { in formation of virtual } \\
\text { enterprises }\end{array}$ & Partnership selection & Numerical example \\
\hline 9 & {$[65]$} & Fuzzy-AHP approach & $\begin{array}{l}\text { Global supplier } \\
\text { selection }\end{array}$ & $\begin{array}{l}\text { An example from a } \\
\text { manufacturing industry }\end{array}$ \\
\hline 10 & {$[66]$} & $\begin{array}{l}\text { Analytical Hierarchy } \\
\text { Process (AHP) and fuzzy } \\
\text { compromise programming }\end{array}$ & $\begin{array}{l}\text { Supplier selection } \\
\text { in quantity discount } \\
\text { environments }\end{array}$ & Numerical example \\
\hline 11 & {$[67]$} & $\begin{array}{l}\text { Fuzzy analytic network } \\
\text { process within multi-person } \\
\text { decision-making scheme }\end{array}$ & $\begin{array}{l}\text { Sustainable supplier } \\
\text { evaluation process }\end{array}$ & $\begin{array}{l}\text { Case study in healthcare } \\
\text { sector in Turkey }\end{array}$ \\
\hline 12 & [68] & Fuzzy analytic network process & Supplier selection & $\begin{array}{l}\text { Indian electronics switch } \\
\text { manufacturing company }\end{array}$ \\
\hline 13 & {$[69]$} & $\begin{array}{l}\text { Fuzzy multiple index } \\
\text { decision-making method } \\
\text { basing on TOPSIS }\end{array}$ & $\begin{array}{l}\text { Partner selection of } \\
\text { cooperation innovation } \\
\text { alliance }\end{array}$ & Numerical example \\
\hline 14 & {$[70]$} & $\begin{array}{l}\text { Fuzzy analytic hierarchy } \\
\text { process and fuzzy technique } \\
\text { and multi-objective linear } \\
\text { programming }\end{array}$ & Supplier selection & $\begin{array}{l}\text { Automobile manufacturing } \\
\text { company }\end{array}$ \\
\hline 15 & {$[71]$} & $\begin{array}{l}\text { Fuzzy set theory in } \\
\text { combination with radial } \\
\text { basis function artificial } \\
\text { neural network }\end{array}$ & $\begin{array}{l}\text { Partner selection in } \\
\text { supply chain management }\end{array}$ & $\begin{array}{l}\text { Chinese electrical } \\
\text { components and } \\
\text { equipment industry }\end{array}$ \\
\hline 16 & {$[72]$} & $\begin{array}{l}\text { Fuzzy inference combined with } \\
\text { the simple fuzzy grid method }\end{array}$ & Supplier evaluation & $\begin{array}{l}\text { Application case in } \\
\text { the automotive industry }\end{array}$ \\
\hline
\end{tabular}


resolve the problem. Considering the multidisciplinary nature of the IJVs, participation of the experts from different fields is crucial. In some group decisionmaking problems, the weight of decision-makers is not equal. Based on their qualifications or other behavioral characteristics in a decision-making, they may contribute inequitably to the decision-making process. Hence, we need an approach for determining the weight of decision-makers. There exist some different approaches in the literature which address the determination of the decision-maker's weight in group decision-making. Bodily [73] developed a direct method for determining the DMs' weights through the designation of voting weights by each DM to a delegation subcommittee made up of other DMs of the group ([74], p. 456). Yue [75] presented a method for computing the DMs weights based on TOPSIS method. In this approach, the positive ideal solution is determined based on the average of a group decision. The negative ideal solution has two parts which are the minimum and maximum matrices of a group decision. Yue [76] also proposed a method based on Euclidean distances between the individual decision and ideal decisions which are the average of individual decisions. Based on the format of the panel in this study, we need an approach in order to consider the qualification of decision-makers as well as their risk-bearing attitudes. In order to calculate the weight of the decision-maker, Eq. (1), the level of knowledge and experience of decision-makers, Eq. (2), should be taken into account. Then, the final weight is obtained from the index of the risk-bearing attitude which is assigned by the head of the panel. Usually, the head of the panel is the top manager who is in charge of the IJV establishing procedure.

$$
\begin{aligned}
& w_{\text {final }_{n}}=\left(\frac{w_{e d, e x_{n}}}{b}\right)^{f}\left(\frac{w_{r_{n}}}{b}\right)^{h}, \\
& w_{e d, e x_{n}}=e d_{n}^{k} e x_{n}^{l}
\end{aligned}
$$

where:

$$
\begin{array}{ll}
w_{e d, e x_{n}}: & \begin{array}{l}
\text { The integrated weight of education and } \\
\text { experience for the } n \text {th decision-maker; }
\end{array} \\
e d: & \begin{array}{l}
\text { Level of education for each decision- } \\
\text { maker; }
\end{array} \\
e x: & \text { Level of experience for each decision- } \\
& \text { maker; } \\
b: & \text { Number of decision-makers in panel; } \\
k: & \text { Education importance rate; } \\
l: & \text { Experience importance rate; } \\
f: & \text { The importance of }\left(\frac{w_{e d, e x_{n}}}{b}\right) ; \\
h: & \text { The importance of }\left(\frac{w_{r_{n}}}{b}\right) ;
\end{array}
$$

$w_{r_{n}}: \quad$ The risk rate of the $n$th decision-maker that will be assigned by panel head.

In addition, it should be noted that we assume Eqs. (3) and (4) to be as follows:

$$
\begin{aligned}
& k+l=1, \\
& f+h=1 .
\end{aligned}
$$

Establishing a panel of decision-makers involves defining an appropriate structure to cover the complexity of IJVs partner selection in the different areas of expertise. The essential appraisal data includes the crucial factors in partner selection procedure. Moreover, a suitable comparison scale must also be selected. These data must be precisely gathered to guarantee the reliability of the proposed model.

\subsection{Step 2: Defining criteria and building AHP model}

According to Subramanian and Ramanathan [77], a multi-criteria decision-making is utilized in different decision areas: operation strategy, product and process design, planning and scheduling resources, project management, and supply chain. The main objective of the MCDM method is selection of the most preferred alternative for decision-makers involved in the problem. According to this reference, The Analytic Hierarchy Process (AHP) proposed by Saaty [12] is very popular and has been applied in a wide variety of areas. The AHP methodology steps are illustrated in Figure 1 (see [78] for more details). Our proposed model is designed based on AHP structure, but a fuzzy extension was used to compare the IJVs partners. In the real decision circumstances, the decision-makers are usually uncertain about their preferences. Moreover, sometimes the information is imperfect which leads to the subjective preferences. In this situation, the fuzzy

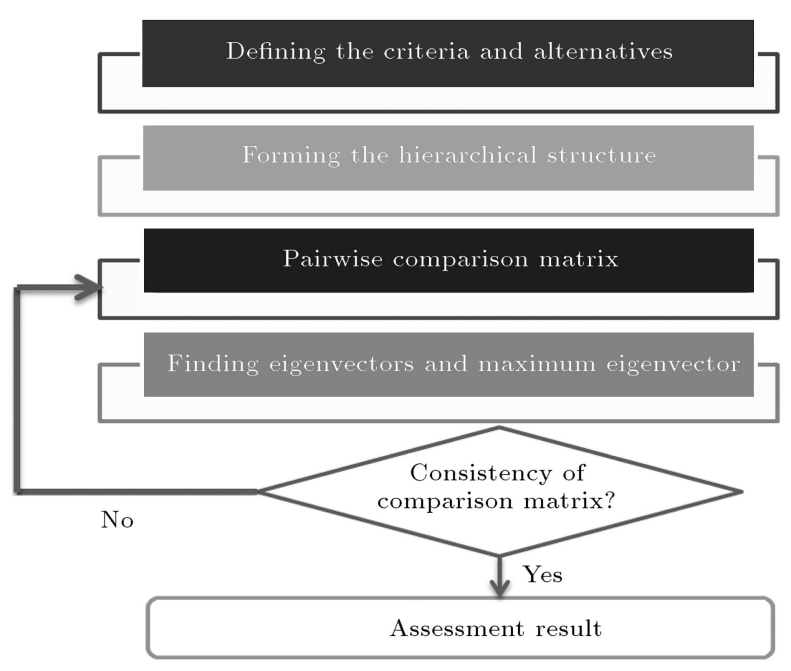

Figure 1. AHP method general process. 
AHP can aid decision-makers to express their opinions quantitatively.

The problem is decomposed based on its main elements. The overall goal is to find the best joint venture partner. The first layer represents the important decision factors that affect the partner selection; the second layer indicates the significant subfactors of the first layer; and the last layer denotes the alternate choices of the partners.

\subsection{Step 3: Defining the relative strengths of criteria and alternatives based on $L R$ fuzzy number, and constructing pair-wise comparison matrices}

The degree of relative importance among elements is usually measured based on the scores assigned by decision-makers. After construction of the AHP model, the experts must fill the judgment matrix accurately. This phase involves pair-wise comparisons on the decision factors at the same level and using a proper scale to present the relative degree of importance. Usually, decision-makers use different illustration setups to show their references. Preference ordering, utility function, fuzzy preference relations, multiplicative preference, and additive relations are different numerical preference structures used in group of decision-making literature [74]. In order to obtain the more exact result in this study, we used two methods (multiplicative and additive relations) and compared the results of NPC IJV partner selection based on both of them. $\mathrm{Xu}$ [74] developed an approach to group decisionmaking problems with different representation formats of linguistic preference relations (additive linguistic preference relations and traditional multiplicative linguistic preference relations). We used the first part of this method for evaluation of the decision-maker's response to the aggregation of the decision-maker's answers to a collective linguistic preference in the calculation of fuzzy matrix. A linguistic additive label set, set (5), and multiplicative, additive linguistic label set, set (6) can be defined as follows:

$$
\begin{array}{ll}
n_{n}^{m}=\left\{n_{n}^{m} \mid n=-l, \cdots, l\right\} ; & l \in Z^{+}, \\
n_{n}^{a}=\left\{n_{n}^{a} \mid n=\frac{1}{l}, \cdots, l\right\} ; & l \in Z^{+} .
\end{array}
$$

Therefore, for additive linguistic label set for each decision-maker, $n=1, \cdots, z$, the relative importance of the $i$ th element over the $j$ th element, $n_{i j_{n}}^{a}$, in a level is defined as follows:

$$
N_{n}^{a}=\left[\begin{array}{ccc}
1 & \cdots & n_{1 n_{n}}^{a} \\
\vdots & \ddots & \vdots \\
n_{n 1_{n}}^{a} & \cdots & 1
\end{array}\right]
$$

where:

$$
\begin{aligned}
& n_{i j_{n}}^{a}=n_{i k_{n}}^{a}-n_{k j_{n}}^{a}+0.5, \quad \forall i, j, k=1, \cdots, n, \\
& 0 \leq n_{i j_{n}}^{a} \leq 1, \quad n_{i j_{n}}^{a}+n_{j i_{n}}^{a}=1, \quad n_{i i_{n}}^{a}=0.5, \\
& \quad \forall i, j=1, \cdots, n, \\
& n_{i j_{n}}^{a}=0.5\left(w_{i_{n}}-w_{j_{n}}+1\right), \quad \forall i, j=1, \cdots, n .
\end{aligned}
$$

$w_{i}$ and $w_{j}$ are the weights of elements $i$ and $j$, respectively.

In addition to multiplicative linguistic label set for each decision-maker, $n=1, \cdots, z$, the relative importance of the $i$ th element over the $j$ th element in a level, $n_{i j_{n}}^{m}$, is addressed as follows:

$$
N_{n}^{m}=\left[\begin{array}{ccc}
1 & \cdots & n_{1 n_{n}}^{m} \\
\vdots & \ddots & \vdots \\
n_{1 n_{n}}^{m} & \cdots & 1
\end{array}\right]
$$

where the following rules and equations will be satisfied in each decision-maker's matrix:

$$
\begin{aligned}
& n_{i j_{n}}^{m}=n_{i k_{n}}^{m} \cdot n_{k j_{n}}^{m}, \quad \forall i, j, k=1, \cdots, n, \\
& n_{i j_{n}}^{m}>0, \quad n_{i j_{n}}^{m}=\frac{1}{n_{j i_{n}}^{m}}, \quad n_{i i_{n}}^{m}=1, \\
& \quad \forall i, j=1, \cdots, n .
\end{aligned}
$$

Now, we transfer each collective format, $N^{a}$ and $N^{m}$, to a fuzzy which illustrates $\tilde{N}^{a}$ and $\tilde{N}^{m}$; thus, for example, the pairwise comparison matrices additive will be:

$$
\tilde{N}^{a}=\left[\begin{array}{ccc}
1 & \cdots & \tilde{n}_{1 n}^{a} \\
\vdots & \ddots & \vdots \\
\tilde{n}_{n 1}^{a} & \cdots & 1
\end{array}\right] .
$$

For a panel of decision-makers consisting of $n$ experts, there are $n$ matrices of judgment which need to be aggregated. According to the method proposed by $\mathrm{Xu}$ [74], all expected additive linguistic preferences relation can be transferred into collective format with the following equation:

$$
\begin{gathered}
\tilde{N}^{a}\left(\tilde{n}_{i j_{1}}^{a}, \tilde{n}_{i j_{2}}^{a}, \cdots, \tilde{n}_{i j_{2}}^{a}\right)=W_{\text {final }_{1}} \tilde{n}_{i j_{1}}^{a} \\
\oplus W_{\text {final }_{2}} \tilde{n}_{i j_{2}}^{a} \oplus \cdots \oplus W_{\text {final }_{z}} \tilde{n}_{i j_{z}}^{a}
\end{gathered}
$$

For the multiplicative format, the following equation is used:

$$
\begin{aligned}
& \tilde{N}^{m}\left(\tilde{n}_{i j_{1}}^{m}, \tilde{n}_{i j_{2}}^{m}, \cdots, \tilde{n}_{i j_{z}}^{m}\right)=\left(\tilde{n}_{i j_{1}}^{m}\right)^{W_{\text {final }_{1}}} \\
& \otimes\left(\tilde{n}_{i j_{2}}^{m}\right)^{W_{\mathrm{final}_{2}}} \otimes \cdots \otimes\left(\tilde{n}_{i j_{z}}^{m}\right)^{W_{\mathrm{final}_{z}}},
\end{aligned}
$$


where $w_{\text {final }_{n}}$ is the weight of $z$ th decision-makers based on the Eq. (1).

A brief description regarding the fuzzy number and the related operations is valuable. A fuzzy number is a special fuzzy set $A=\left\{\left(x, \mu_{\tilde{N}(x)}\right), x \in R\right\}$ where $x$ takes values on the real line $R:-\infty<x<+\infty$, and $\mu_{\tilde{N}(x)}$ is a continuous plotting from $R$ to the closed interval $[0,1]$.

In comparison with other fuzzy number types, LR fuzzy numbers are proposed by Dubois and Prade [79] for obtaining fast computational procedures for fuzzy number operation [80]. The definition of LR fuzzy number and basic operations is described in this section.

We define $\tilde{N}_{i j}$ as a LR fuzzy number which is defined as follows:

$$
\mu_{\tilde{N}(x)}=\left\{\begin{array}{l}
L\left(\frac{m-x}{\alpha}\right) x \leq m \\
R\left(\frac{x-m}{\beta}\right) x>m
\end{array}\right.
$$

where $m$ is the mean value of $\tilde{N}(x)$ and $\alpha$ and $\beta$ are left and right spreads, correspondingly.

For two LR fuzzy numbers $A=(a, \alpha, \beta)_{\mathrm{LR}}$ and $B=(b, \gamma, \theta)_{\mathrm{LR}}$, the addition, subtraction, multiplication, division, and inverse operation are defined, respectively, by Eqs. (18) to (23):

$$
\begin{aligned}
& (a, \alpha, \beta)_{\mathrm{LR}}+(b, \gamma, \theta)_{\mathrm{LR}}=(a+b, \alpha+\gamma, \beta+\theta)_{\mathrm{LR}} \\
& (a, \alpha, \beta)_{\mathrm{LR}}-(b, \gamma, \theta)_{\mathrm{LR}}=(a-b, \alpha+\theta, \beta+\gamma)_{\mathrm{LR}} \\
& (a, \alpha, \beta)_{\mathrm{LR}} \otimes(b, \gamma, \theta)_{\mathrm{LR}}=(a b, \alpha \gamma+b \alpha, a \theta+b \beta)_{\mathrm{LR}},
\end{aligned}
$$

$$
\left((a, \alpha, \beta)_{\mathrm{LR}}\right)^{t} \#\left(a^{t}, \operatorname{ta} \alpha, \operatorname{ta} \beta\right),
$$

where two numbers are positive:

$$
\begin{aligned}
& (a, \alpha, \beta)_{\mathrm{LR}} \oslash(b, \gamma, \theta)_{\mathrm{LR}}=\left(\frac{a}{b}, \frac{\theta a+\alpha b}{b^{2}}, \frac{\gamma a+\beta b}{b^{2}}\right)_{\mathrm{LR}}, \\
& A^{-1}=\left(a^{-1}, \beta a^{-2}, \alpha a^{-2}\right)_{\mathrm{RL}} .
\end{aligned}
$$

The triangular LR fuzzy number is selected for this study. $L$ and $R$ are linear functions in Eq. (17). Hence, we rewrite this equation as Eq. (24). A triangular fuzzy number can be written as $(m, \alpha, \beta)_{\mathrm{LR}}$. Figure 2 shows a set of LR fuzzy number $\{A, B, C\}$ with the following membership functions:

$$
\begin{aligned}
& \mu_{\tilde{A}, \tilde{B}, \tilde{C}(x)}=\left\{\begin{array}{l}
\left(\frac{m-x}{\alpha}\right) x \leq m \\
\left(\frac{x-m}{\beta}\right) x>m
\end{array}\right. \\
& A=\left(m_{A}, \alpha, \beta\right)_{\mathrm{LR}},
\end{aligned}
$$

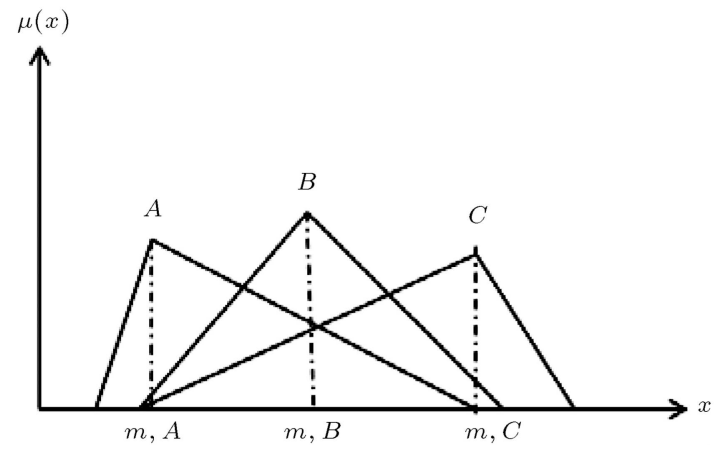

Figure 2. Fuzzy membership functions for a set triangular LR fuzzy number.

where:

$$
\begin{aligned}
& \alpha<\beta, \\
& B=\left(m_{B}, \alpha, \beta\right)_{\mathrm{LR}},
\end{aligned}
$$

where:

$$
\begin{aligned}
& \alpha=\beta, \\
& A=\left(m_{C}, \alpha, \beta\right)_{\mathrm{LR}},
\end{aligned}
$$

where:

$$
\alpha>\beta \text {. }
$$

Fuzzy sets aid decision-makers to handle the uncertainty of human's judgment [81]. Multi-Criteria Decision-Making is also used to attain the global ranking of potential partners and select a suitable partner considering the different criteria. Hence, fuzzy AHP method brings the most advantages for obtaining a reliable solution for this decision problem.

It should be noted that we supposed $L(x)=$ $R(x)=\max \{0,1-x\}$. Hence, for example, the fuzzy number, $\widetilde{0.5}$, in additive format is $\left\{(m, \alpha, \beta)_{\mathrm{LR}}=\right.$ $(0.5,0.0275,0.0275)\}$; see Table 4 for more details.

\subsection{Step 4: Evaluating fuzzy eigenvalue and normalization}

In order to indicate the relative degree of importance between decision criteria, the priority weight vector was calculated using an eigenvalue method. The main eigenvector could be computed and converted to the priority weight vector once normalized. The Consistency Index (CI) and Consistency Ratio (CR) should be calculated based on Saaty [12] to evaluate the consistency judgment for each comparison matrix and AHP model. The formula for obtaining the eigenvector is Eq. (28):

$$
N w=\lambda_{\max } w
$$

where $N$ is the judgment matrix and $\lambda_{\max }$ is the 
principle eigenvalue of $N$ as follows:

$$
\lambda_{\max }=\sum_{i=1}^{n} \frac{(N w)_{i}}{n w_{i}}
$$

where we define Eqs. (30) and (31) as follows:

$$
\begin{gathered}
w=\lim \frac{N^{k} \cdot e}{e^{T} \cdot N^{k} \cdot e}, \\
k \rightarrow \infty, \\
e=(1,1, \cdots, 1), \\
w_{i}=r_{i} /\left(r_{1}+r_{2}+\cdots+r_{m}\right) .
\end{gathered}
$$

$w_{i}$ as the components of the normalized eigenvector corresponding to $\lambda_{\max }$, and $r_{i}$ is the geometric mean of each row as follows:

$$
r_{i}=\left(\prod_{j=1}^{m} n_{i j}\right)^{1 / m}
$$

where $n_{i j}$ is the relative importance of the $i$ th element over the $j$ th element in a comparison matrix.

According to Buckley [82], a fuzzy positive reciprocal matrix $\tilde{N}=\left[\tilde{n}_{i j}\right], \tilde{r}_{i}$ and fuzzy weight $\tilde{w}_{i}$ corresponding to each criterion are defined as follows:

$$
\begin{aligned}
& \tilde{r}_{i}=\left(\tilde{r}_{i} \otimes \tilde{r}_{i} \otimes \cdots \otimes \tilde{r}_{i}\right)^{1 / m} \\
& \tilde{w}_{i}=\tilde{r}_{i} \otimes\left(\tilde{r}_{1} \oplus \cdots \oplus \tilde{r}_{m}\right)^{-1} .
\end{aligned}
$$

A fuzzy positive reciprocal matrix $\tilde{N}=\left[\tilde{n}_{i j}\right]$ is consistent if and only if:

$$
\tilde{n}_{i k} \odot \tilde{n}_{k i} \approx \tilde{n}_{i j} .
$$

If the fuzzy positive reciprocal matrix is not consistent, we need to review the estimates of the ratios in order to improve the estimation of the fuzzy weights.

The interval of preference relation and fuzzy judgment matrix needs to be normalized. Wang and Elang [83] proposed the normalization methods for interval and fuzzy weights which modified the defective of the other normalization methods based on interval and fuzzy arithmetics. For a set of fuzzy weights which are independent and need to be summed to one, the normalization can be obtained via Eqs. (35) and (36):

$$
\begin{aligned}
& \left(\hat{w}_{i}\right)_{\propto}^{L}=\max \left\{\left(w_{i}\right)_{\propto}^{L}, 1-\sum_{j \neq i}\left(w_{j}\right)_{\propto}^{U}\right\}, \\
& \left(\hat{w}_{i}\right)_{\propto}^{U}=\max \left\{\left(w_{i}\right)_{\propto}^{U}, 1-\sum_{j \neq i}\left(w_{j}\right)_{\propto}^{L}\right\} .
\end{aligned}
$$

It should be noted that for an LR fuzzy number with
$L$ and $R$ functions, the $\alpha$-cut is identified as follows:

$$
\begin{aligned}
& \propto=L\left[\frac{m-x}{a}\right] \Rightarrow \frac{m-x}{a}=L^{-1}(\propto) \Rightarrow \\
& \tilde{A}_{\propto}^{L}=x=m-a L^{-1}(\propto), \\
& \propto=R\left[\frac{X-m}{b}\right] \Rightarrow \frac{x-m}{b}=R^{-1}(\propto) \Rightarrow \\
& \tilde{A}_{\propto}^{R}=x=m+b R^{-1}(\propto) .
\end{aligned}
$$

Therefore, $\tilde{A}_{\propto}=\left[\tilde{A}_{\propto}^{L}, \tilde{A}_{\propto}^{R}\right]$ is the corresponding $\propto$-cut. It should be noted that $\propto$ value is 0.95 in our model.

\subsection{Step 5: Estimating the rate of alternatives and ranking}

In order to rank the alternatives, we need a method for ranking and comparing the fuzzy sets. Wang et al. ([84], p. 2072), proposed a procedure for ranking fuzzy numbers based on the left and right deviation degrees of LR fuzzy number. This algorithm is described for ranking LR fuzzy number in this section.

For a set of LR fuzzy numbers, $A_{1}, A_{2}, \cdots, A_{n}$, where $A_{i}=\left(m_{i}, \alpha_{i}, \beta_{i}\right)_{\mathrm{LR}}, x_{\min }$ and $x_{\max }$ are the infimum and supremum of support sets of these fuzzy numbers, respectively.

First of all, the membership functions of minimal and maximal reference sets should be determined as follows:

$$
\mu_{A_{\min }}(x)= \begin{cases}\frac{x_{\max }-x}{x_{\max }-x_{\min }}, & \text { if } x \in S \\ 0, & \text { otherwise }\end{cases}
$$

and:

$$
\mu_{A_{\max }}(x)= \begin{cases}\frac{x-x_{\min }}{x_{\max }-x_{\min }}, & \text { if } x \in S \\ 0, & \text { otherwise }\end{cases}
$$

where $S$ is the support set for these fuzzy numbers.

We need to calculate the left and right deviation degrees based on Eqs. (41) and (42):

$$
d_{i}^{L}=\int_{x_{\min }}^{a_{i}}\left(\mu_{A_{\min }}(x)-\mu_{A_{i}^{L}}(x)\right) d x,
$$

and:

$$
d_{i}^{R}=\int_{b_{i}}^{x_{\max }}\left(\mu_{A_{\max }}(x)-\mu_{A_{i}^{R}}(x)\right) d x,
$$

where $a_{i}$ is the abscissa of the crossover point of $\mu_{A_{i}^{L}}(x)$ and $\mu_{A_{\min }}(x)$, and $b_{i}$ is that of $\mu_{A_{\max }}(x)$ and $\mu_{A_{i}^{R}}(x)$, $i=1,2, \cdots, n$.

For a LR fuzzy, its expectation value of centroid 
is defined as follows:

$$
M_{i}=\frac{\int_{m_{i}-\alpha_{i}}^{m_{i}+\beta_{i}} x \mu_{A_{i}}(x) d x}{\int_{m_{i}-\alpha_{i}}^{m_{i}+\beta_{i}} \mu_{A_{i}}(x) d x} .
$$

After this step, the relative closeness coefficient should be defined as follows:

$$
d_{i}^{*}=\frac{d_{i}^{L}}{1+d_{i}^{R}}, \quad i=1,2, \cdots, n,
$$

where the greater $d_{i}^{*}$ is, the greater the respective fuzzy number, $A_{i}$, will be.

Then, the transfer coefficient is computed as follows:

$$
\lambda_{i}=\frac{M_{i}-M_{\min }}{M_{\max }-M_{\min }}
$$

where $M_{\max }=\max \left\{M_{1}, M_{2}, \cdots, M_{n}\right\}, M_{\min }=$ $\min \left\{M_{1}, M_{2}, \cdots, M_{n}\right\}$, and $M_{\max } \neq M_{\min }$. The ranking index will be calculated as follows:

$$
d_{i}= \begin{cases}\frac{d_{i}^{L} \lambda_{i}}{1+d_{i}^{R}\left(1-\lambda_{i}\right)}, & M_{\max } \neq M_{\min } \\ & i=1,2, \cdots, n \\ \frac{d_{i}^{L}}{1+d_{i}^{R}}, & M_{\max }=M_{\min } \\ & i=1,2, \cdots, n .\end{cases}
$$

Finally, the ranking order of LR fuzzy numbers $A_{i}$ and $A_{j}$ can be defined as follows:

(1) $A_{i} \succ A_{j}$, if and only if $d_{i}>d_{j}$,

(2) $A_{i} \prec A_{j}$, if and only if $d_{i}<d_{j}$,

(3) $A_{i} \sim A_{j}$, if and only if $d_{i}=d_{j}$.

\section{Application to a real case study}

The proposed methodology is applied to NPC in order to select the IJV partner. In this section, a brief description of NPC and its policy for international business activities are described. Then, our introduced method for partner selection is illustrated, and the results are discussed. Finally, the implication of this methodology for NPC is enlightened.

\subsection{National Iranian petrochemical company and IJVs agreements}

According to Khoshrou [85], Iran, with $9 \%$ of the world's crude oil and $18 \%$ of its gas reserves, has a strategic position in the Middle East. The Iranian government makes every effort to diverge from an economy based on oil exports. Hence, the development of the petrochemical industry has been selected as its highest national priorities. Large quantities of ethane from natural gas sustain ethylene production at low cost. This opportunity, as well as the use of large ethane crackers and low production costs, together with the competitive advantages for NPC would be achievable. This reference pointed out that the production cost of ethylene is about 0.6 time in the Middle East in comparison to the USA. NPC in its long-term vision needs financial resources for new petrochemical projects in order to maximize local participation and maintain its competitive advantage in the Middle East. Petrochemical Investment Bank, Islamic Development Bank, Iranian banks, Bonds, prioritization, and establishment of IJVs are solutions for raising the funding for new projects. IJVs, with knowledge and technology, are also transferring aid for NPC to achieve the first place in the Middle East in terms of production value and create high value-added petrochemical products and hydrocarbons resources of the country. With this strategy, not only more added value products are created, but also the domestic market would be developed. The selection of appropriate partner for establishing joint ventures is a strategic decision for NPC. The political relations between the countries, the institutional frameworks, market structure, and the other micro and macro factors should be considered. Moreover, a lot of sources of uncertainties in the decision-making process with the sparse information are added to the complexity of the problem. Developing a systematic approach to decision-making in such a complex situation can aid top managers to facilitate decision-making and alleviate the uncertainties [78]. The conceptual framework for establishing IJVs for NPCs, including the drivers, the problem context, and long-term benefits, is illustrated in Figure 3.

\subsection{Defining criteria and building the model}

Based on the group of experts' attitudes in addition to the literature and the results of previous works, this paper chooses human resources, equipment, facility, finance, technology, experience, management, regulation, and trust (as nine strategic issues) as the first level of criteria for joint venture partner selection in the petrochemical industry. Each criterion entails a number of detailed metrics, which are also recognized in this step. The data collection procedure consists of distributing a set of the questionnaire through interviewing the professional of the industries who are directly involved in joint venture agreement procedure and researchers who are major in strategic management and international business. The industrial expertise includes two bachelors of chemical engineering, master of accounting and law, and three PhDs in management field. The weight of decision-makers is illustrated in Table 3. In this study, based on the head of panel opinion, we assumed that $k=0.4, l=0.6, f=0.8$ and $h=0.2$. The final weights in Table 3 have been 
Table 3. The weights of decision-makers.

\begin{tabular}{lcccccc}
\hline \multicolumn{1}{c}{ DMs } & DM1 & DM2 & DM3 & DM4 & DM5 & DM6 \\
\hline Education & 60 & 60 & 80 & 100 & 100 & 100 \\
Experience & 100 & 100 & 100 & 80 & 70 & 70 \\
Risk & 40 & 60 & 30 & 20 & 40 & 30 \\
Weight (education, experience) & 81.52 & 81.52 & 91.46 & 87.47 & 80.73 & 80.73 \\
Final weight & 0.17 & 0.18 & 0.17 & 0.15 & 0.17 & 0.16 \\
\hline
\end{tabular}

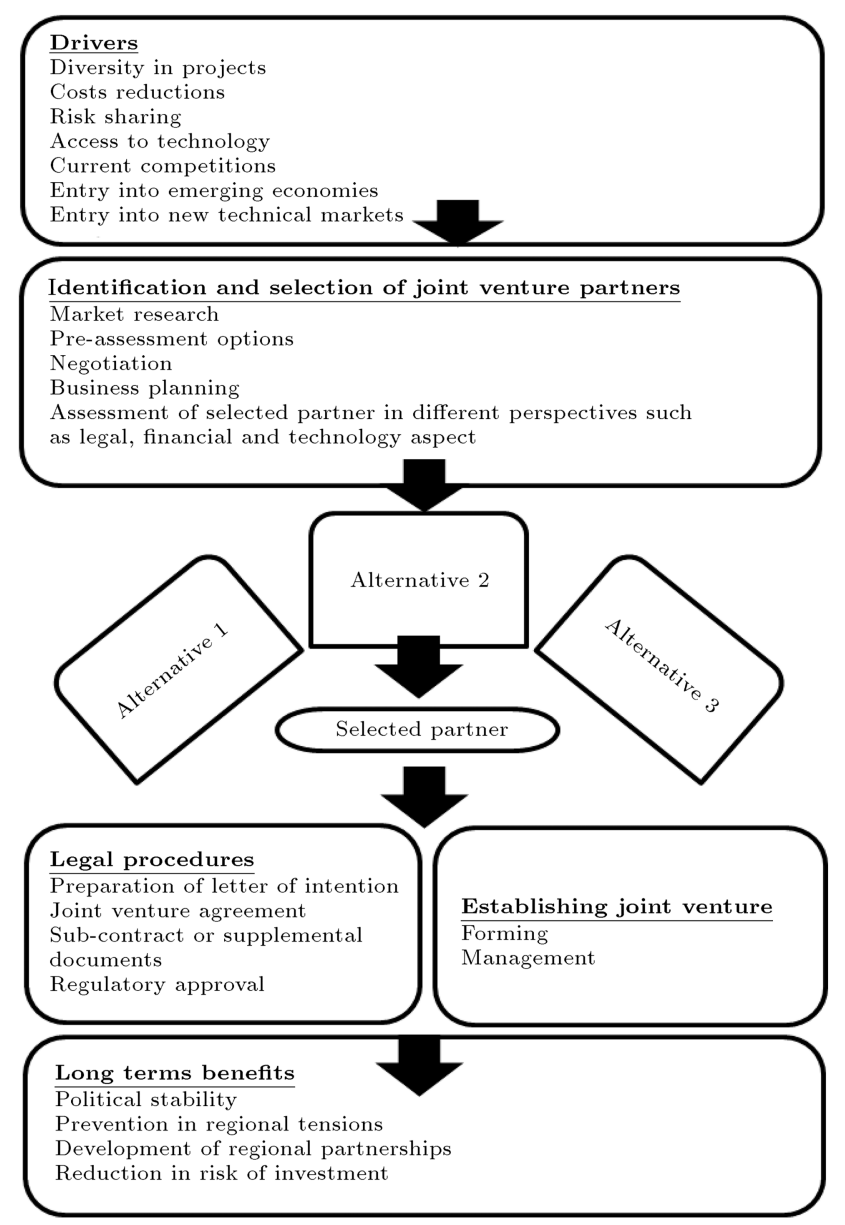

Figure 3. Conceptual framework for IJVs agreement in NPC.

normalized to sum 1 . The criteria and sub-criteria were constructed based upon the panels' opinions on each element. The AHP model contains the global goal, criteria, sub-criteria, and the decision alternatives. Figure 4 illustrates the proposed model based on expert interview and literature review.

\subsection{Performing pairwise comparison}

When AHP model is built, prioritization process starts from level 2 and continues to levels 3 and 4 to find the relative importance of the factors in each level. A total of 6 experts involved in the panel expressed their experiences. Two multiplicative and additive questionnaires were used to collect their opinions as pairwise comparisons for models elements. By $\mathrm{Xu}$ [74] method, the collective and aggregated relative preference was performed. To apply AHP method for achieving weights of criteria, decision-makers use the linguistic variables shown in Table 4 to perform pairwise comparisons between criteria. We defined a broad range to give maximum flexibility to policymakers in judgment. However, this range increased the complexity of matrix computations. If the judgments matrix of the experts were inconsistent, we would request them to replicate the comparison until the consistency index is less than 0.1. We used Matlab R2014a to find fuzzy eigenvalues and eigenvector. Next, we combined the priorities of the whole hierarchy to find the global importance weights and perform the ranking. The $S$ set based on $\mathrm{Xu}$ [74] method in additive format, $S_{a}$, and multiplicative, $S_{m}$, are defined in Table 4.

\subsection{Results and alternative ranking}

The ranked aggregated rate of criteria and sub-criteria (in levels 2 and 3 ) of the hierarchy I additive and multiplicative format is shown in Tables 5 and 6 , respectively. Each decision-maker forms the fuzzy decision matrix in which each alternative is evaluated with respect to each criterion. Through integrating the final weights of the introduced model and their ranking, the final scores of potential partners $\mathrm{A}, \mathrm{B}$, and $\mathrm{C}$ are $0.0004,0.0016$, and 0.0023 in additive format and $0.0014,0.0032,0.0056$ in multiplicative format, respectively. The result points out that Company $\mathrm{C}$ should be selected. The consistency ratio of the whole system in the additive and the multiplicative cases is 0.09 and 0.03 , respectively. It should be noted that the results of two methods are consistent and have led to the similar results of the alternatives ranking. However, as the additive model is easier for decisionmaker, it is recommended as a convenient method for the partner selection. The outcomes of the study of Choo and Wedley [86] also confirm the efficiency of additive model for easier application for decisionmakers. The authors examined the advantages and limitations of the additive and multiplicative aggregation rules and emphasized that in additive model, questioning procedures are better understood by the decision-makers in practice. 


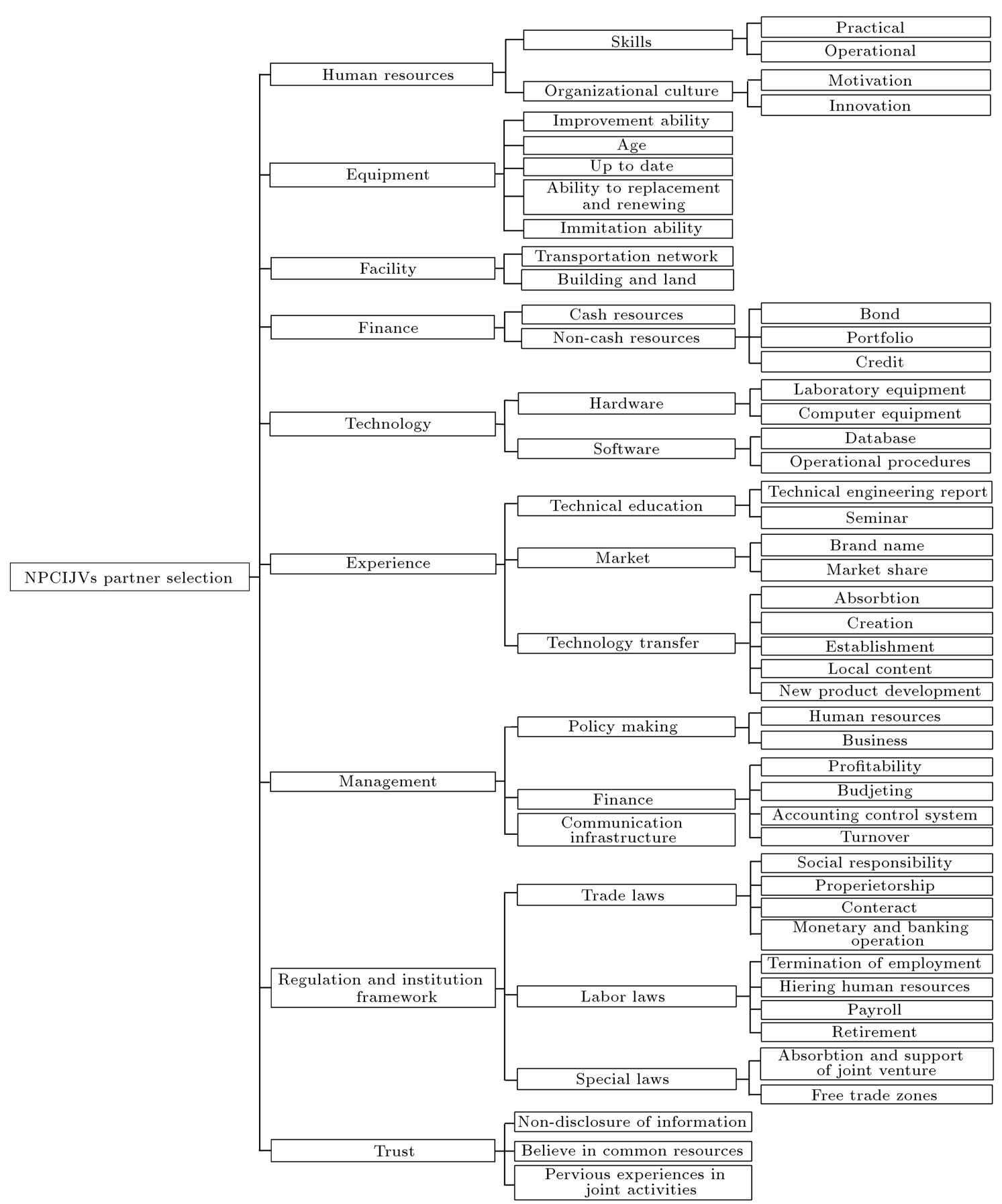

Figure 4. The hierarchical structure for IJV partner selection of NPC.

\subsection{Managerial and industrial implications}

Establishing a systematic way for selecting joint venture partners is an essential deliverable outcome of this study for NPC. The interviewed experts indicated that the structure of the model helped them to evaluate different perspectives of the problem. Moreover, they said that the current method of selecting the partner is carried out based on subjective judgments and through several managerial and professional meetings. However, the hierarchical structure developed in this study is a valuable tool to evaluate the potential partners more precisely and equitably. The head of the panel believed that this study is practical and highly recommended to be applied in the future joint venture partner selection procedure. The structure of the decision-making panel reflects the multidisciplinary nature of the problem. In this study, six industrial experts, scholars, and managers are involved in the process. Considering a panel with more experts can decrease the assignment of the current panel and may increase the accuracy of the results. The equipment of the partner, its financial capacity, trusts, and 
Table 4. Linguistic variable for pairwise comparison as well as fuzzy additive and multiplicative formats.

\begin{tabular}{lcclllllllll}
\hline \multicolumn{1}{c}{ Linguistic preference } & Code & \multicolumn{3}{c}{ Multiplicative } & & \multicolumn{5}{c}{ Additive } \\
\hline Extremely not important & ENI & $1 / 9:$ & $(0.11111$ & 0.00617284 & $0.00617)$ & $0.0:$ & $(0.0$ & 0.0 & 0.0 \\
Strongly not important & SNI & $1 / 8:$ & $(0.125$ & 0.007812 & $0.007812)$ & $0.11:$ & $(0.11$ & 0.055 & $0.055)$ \\
Not very important & NVI & $1 / 7:$ & $(0.14285$ & 0.0102040 & $0.010204)$ & $0.12:$ & $(0.12$ & 0.055 & $0.055)$ \\
Not important & NI & $1 / 6:$ & $(0.16666$ & 0.013888 & $0.0138888)$ & $0.14:$ & $(0.14$ & 0.055 & $0.055)$ \\
Not important (medium) & NIM & $1 / 5:$ & $(0.2$ & 0.02 & $0.02)$ & $0.16:$ & $(0.16$ & 0.055 & $0.055)$ \\
Slightly not important & SNI & $1 / 4:$ & $(0.25$ & 0.03125 & $0.03125)$ & $0.2:$ & $(0.2$ & 0.055 & $0.055)$ \\
Much less equally important & MLEI & $1 / 3:$ & $(0.33333$ & 0.0555 & $0.0555555)$ & $0.25:$ & $(0.25$ & 0.055 & $0.055)$ \\
Less equally important & LEI & $1 / 2:$ & $(0.5$ & 0.125 & $0.125)$ & $0.36:$ & $(0.36$ & 0.055 & $0.055)$ \\
Equally important & EI & $1:$ & $(1$ & 0.5 & $0.5)$ & $0.5:$ & $(0.5$ & 0.0275 & $0.0275)$ \\
More equally important & MEI & $2:$ & $(2$ & 0.5 & $0.5)$ & $0.64:$ & $(0.64$ & 0.0275 & $0.0275)$ \\
Much more equally important & MMEI & $3:$ & $(3$ & 0.5 & $0.5)$ & $0.75:$ & $(0.75$ & 0.0275 & $0.0275)$ \\
Slightly important & SI & $4:$ & $(4$ & 0.5 & $0.5)$ & $0.8:$ & $(0.8$ & 0.0275 & $0.0275)$ \\
Medium important & MI & $5:$ & $(5$ & 0.5 & $0.5)$ & $0.84:$ & $(0.84$ & 0.0275 & $0.0275)$ \\
Important & I & $6:$ & $(6$ & 0.5 & $0.5)$ & $0.86:$ & $(0.86$ & 0.0275 & $0.0275)$ \\
Very important & VI & $7:$ & $(7$ & 0.5 & $0.5)$ & $0.88:$ & $(0.88$ & 0.0275 & $0.0275)$ \\
Strongly very important & SVI & $8:$ & $(8$ & 0.5 & $0.5)$ & $0.89:$ & $(0.89$ & 0.0275 & $0.0275)$ \\
Extremely very important & EVI & $9:$ & $(9$ & 0.5 & $0.5)$ & $1:$ & $(1$ & 0.0275 & $0.0275)$ \\
\hline
\end{tabular}

management skills are the most important criteria for establishing the durable partners in the international joint venture of NPC. As mentioned before, the need for financial resources is the main objective of NPC for launching joint venture agreements. Moreover, the management skill can be considered as an essential facilitator for performing the subject of the contract. Hence, this result can support the opinions of $[18,19]$ that advise the objective of the joint venture to be critical indicator in performance measurement and the successful establishment of these strategic partners. Most of strategic collaborations have been formed in $R \& D$ and modern technology industries [1]. The essential outcome of this collaboration and joint agreements is the transfer of knowhow and knowledge between partners. Selecting the best partner could lead to a sustainable partnership for NPC that improves knowledge capabilities in terms of innovation, product development, intellectual capital, and human resource development. Oil and Gas sectors in Iran are considered high-tech sectors and need further modifications of the general framework, organized ways, and efficient solutions for establishing joint agreements.

\section{Conclusion and future research}

In this paper, we developed a group decision-making model based on AHP, fuzzy linguistic preferences relation (additive and multiplicative) and the most important parameters for establishing a joint venture with National Iranian Petrochemical Company (NPC). These parameters are derived from our survey of previous literature and several interviews with Iranian oil Industry's experts. The proposed approach decreases computational complication in terms of the different factors involved in partner selection procedure. Simultaneously, the introduced methodology handles uncertainty and multilayers decision-making by combining effective building blocks. The contribution of this study is developing a fresh construction for partner selection for international joint ventures and application in a real-life case study in order to present an operational guideline to the petrochemical industries. The method of this study can be used for other industries with some modifications. This study can be extended by assessing the model by Fuzzy Analytical Network Process approach considering the relationship among criteria and applying sensitivity analysis of estimated coefficient to criteria as well as using parallel teams of decision-makers. Moreover, determining the ownership share of partners with MODM (MultiObjective Decision-Making) approach with the neural network [87], ranking IJV project delaying factors [88], ranking the stakeholder(s) involvement challenges in IJV project [89], and considering market strategy for partner selection [90] can also be proposed for future studies. 
Table 5. The ranking of criteria and sub-criteria (additive method).

\begin{tabular}{|c|c|c|c|c|c|c|c|c|}
\hline Criteria-L1 & $\begin{array}{c}\text { Ranking } \\
\text { index }(d) \\
{[84]}\end{array}$ & Ranking & $\begin{array}{c}\text { Sub- } \\
\text { criteria- } \\
\text { L2 } \\
\end{array}$ & $\begin{array}{c}\text { Ranking } \\
\text { index }(d) \\
{[84]}\end{array}$ & Ranking & $\begin{array}{c}\text { Sub- } \\
\text { criteria- } \\
\text { L3 }\end{array}$ & $\begin{array}{c}\text { Ranking } \\
\text { index }(d) \\
{[84]}\end{array}$ & Ranking \\
\hline \multirow{4}{*}{$\mathrm{C} 1$} & \multirow{4}{*}{0.0031} & \multirow{4}{*}{8} & \multirow{2}{*}{ C11 } & \multirow{2}{*}{0.044} & \multirow{2}{*}{1} & C111 & 0.0154 & 2 \\
\hline & & & & & & C112 & 0.0161 & 1 \\
\hline & & & \multirow{2}{*}{$\mathrm{C} 12$} & \multirow{2}{*}{0.0163} & \multirow{2}{*}{2} & $\mathrm{C} 121$ & 0.0258 & 1 \\
\hline & & & & & & $\mathrm{C} 122$ & 0.0097 & 2 \\
\hline \multirow{5}{*}{$\mathrm{C} 2$} & \multirow{5}{*}{0.0127} & \multirow{5}{*}{1} & $\mathrm{C} 21$ & 0.0108 & 2 & & & \\
\hline & & & $\mathrm{C} 22$ & 0.0061 & 3 & & & \\
\hline & & & $\mathrm{C} 23$ & 0.0034 & 5 & & & \\
\hline & & & $\mathrm{C} 24$ & 0.0041 & 4 & & & \\
\hline & & & $\mathrm{C} 25$ & 0.0142 & 1 & & & \\
\hline \multirow{2}{*}{ C3 } & \multirow{2}{*}{0.0019} & \multirow{2}{*}{9} & C31 & 0.0388 & 1 & & & \\
\hline & & & C32 & 0.0215 & 2 & & & \\
\hline \multirow{4}{*}{$\mathrm{C} 4$} & \multirow[t]{4}{*}{0.0122} & 2 & C41 & 0.0319 & 1 & & & \\
\hline & & & \multirow{3}{*}{$\mathrm{C} 42$} & \multirow{3}{*}{0.0284} & \multirow{3}{*}{2} & C421 & 0.0061 & 3 \\
\hline & & & & & & $\mathrm{C} 422$ & 0.0115 & 2 \\
\hline & & & & & & $\mathrm{C} 423$ & 0.0179 & 1 \\
\hline & & & C.51 & 0.0214 & 1 & C511 & 0.0262 & 1 \\
\hline C5 & 0.0039 & 7 & 051 & 0.0214 & 1 & C512 & 0.0093 & 2 \\
\hline 0 & . & 1 & C 52 & 0.0063 & 2 & C521 & 0.0214 & 1 \\
\hline & & & 052 & 0.0003 & 2 & $\mathrm{C} 522$ & 0.0142 & 2 \\
\hline & & & C61 & 00059 & 3 & C611 & 0.0078 & 2 \\
\hline & & & 001 & 0.0059 & 3 & $\mathrm{C} 612$ & 0.0091 & 1 \\
\hline & & & $\mathrm{C} 62$ & 00092 & 2 & $\mathrm{C} 621$ & 0.0105 & 2 \\
\hline & & & 002 & 0.0092 & 2 & $\mathrm{C} 622$ & 0.0251 & 1 \\
\hline C6 & 0.0044 & 6 & & & & C631 & 0.0084 & 3 \\
\hline & & & & & & C632 & 0.0077 & 4 \\
\hline & & & C63 & 0.0114 & 1 & C633 & 0.0147 & 2 \\
\hline & & & & & & C634 & 0.0076 & 5 \\
\hline & & & & & & $\mathrm{C} 635$ & 0.0265 & 1 \\
\hline & & & $\mathrm{C} 71$ & 0019 & 2 & $\mathrm{C} 711$ & 0.005 & 2 \\
\hline & & & 11 & 0.013 & 2 & $\mathrm{C} 712$ & 0.0088 & 1 \\
\hline $\mathrm{C} 7$ & 0.0076 & 4 & & & & $\mathrm{C} 721$ & 0.0072 & 3 \\
\hline & & & $\mathrm{C} 7 \mathrm{P}$ & 00314 & 1 & $\mathrm{C} 722$ & 0.0072 & 3 \\
\hline & & & 012 & 0.0314 & 1 & C723 & 0.0073 & 2 \\
\hline & & & & & & $\mathrm{C} 724$ & 0.0168 & 1 \\
\hline & & & C73 & 0.0098 & 3 & & & \\
\hline & & & & & & C811 & 0.0025 & 4 \\
\hline & & & C81 & 0.0211 & 2 & C812 & 0.0038 & 3 \\
\hline & & & & 0.0211 & 2 & C813 & 0.0087 & 2 \\
\hline & & & & & & C814 & 0.0206 & 1 \\
\hline C8 & 00052 & 5 & & & & C821 & 0.0037 & 3 \\
\hline & & & C82 & 0.0106 & 3 & $\mathrm{C} 822$ & 0.0193 & 1 \\
\hline & & & & & & $\mathrm{C} 823$ & 0.0093 & 2 \\
\hline & & & & & & $\mathrm{C} 824$ & 0.0032 & 4 \\
\hline & & & C83 & 0.0249 & 1 & C831 & 0.014 & 2 \\
\hline & & & 083 & 0.0249 & 1 & $\mathrm{C} 832$ & 0.0216 & 1 \\
\hline & & & C91 & 0.013 & 2 & & & \\
\hline C9 & 0.0094 & 3 & C92 & 0.0364 & 1 & & & \\
\hline & & 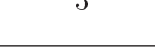 & C93 & 0.0109 & 3 & & & \\
\hline
\end{tabular}


Table 6. The ranking of criteria and sub-criteria (multiplicative method).

\begin{tabular}{|c|c|c|c|c|c|c|c|c|}
\hline Criteria-L1 & $\begin{array}{c}\text { Ranking } \\
\text { index }(d) \\
{[84]}\end{array}$ & Ranking & $\begin{array}{c}\text { Sub- } \\
\text { Criteria- } \\
\text { L2 } \\
\end{array}$ & $\begin{array}{c}\text { Ranking } \\
\text { index }(d) \\
{[84]}\end{array}$ & Ranking & $\begin{array}{c}\text { Sub- } \\
\text { Criteria- } \\
\text { L3 } \\
\end{array}$ & $\begin{array}{c}\text { Ranking } \\
\text { index }(d) \\
{[84]}\end{array}$ & Ranking \\
\hline \multirow{5}{*}{$\mathrm{C} 1$} & \multirow{5}{*}{0.02945} & \multirow{5}{*}{8} & \multirow{3}{*}{ C11 } & \multirow{3}{*}{0.374} & \multirow{3}{*}{1} & C111 & 0.1155 & 2 \\
\hline & & & & & & $\mathrm{C} 112$ & 0.1207 & 1 \\
\hline & & & & & & & & \\
\hline & & & $\mathrm{C} 12$ & 0.138 & 2 & $\mathrm{C} 121$ & 0.1935 & 1 \\
\hline & & & & & & $\mathrm{C} 122$ & 0.0727 & 2 \\
\hline \multirow{5}{*}{$\mathrm{C} 2$} & \multirow{5}{*}{0.12065} & \multirow{5}{*}{1} & $\mathrm{C} 21$ & 0.0918 & 2 & & & \\
\hline & & & $\mathrm{C} 22$ & 0.05185 & 3 & & & \\
\hline & & & $\mathrm{C} 23$ & 0.0289 & 5 & & & \\
\hline & & & $\mathrm{C} 24$ & 0.03485 & 4 & & & \\
\hline & & & $\mathrm{C} 25$ & 0.1207 & 1 & & & \\
\hline \multirow{2}{*}{ C3 } & \multirow{2}{*}{0.01805} & \multirow{2}{*}{9} & C31 & 0.3298 & 1 & & & \\
\hline & & & $\mathrm{C} 32$ & 0.18275 & 2 & & & \\
\hline \multirow{4}{*}{$\mathrm{C} 4$} & \multirow{4}{*}{0.1159} & \multirow{4}{*}{2} & $\mathrm{C} 41$ & 0.27115 & 1 & & & \\
\hline & & & & & & $\mathrm{C} 421$ & 0.04575 & 3 \\
\hline & & & $\mathrm{C} 42$ & 0.2414 & 2 & $\mathrm{C} 422$ & 0.08625 & 2 \\
\hline & & & & & & $\mathrm{C} 423$ & 0.13425 & 1 \\
\hline \multirow{4}{*}{ C5 } & \multirow{4}{*}{0.03705} & \multirow{4}{*}{7} & \multirow{2}{*}{ C51 } & \multirow{2}{*}{0.1819} & 1 & C511 & 0.1965 & 1 \\
\hline & & & & & & C512 & 0.06975 & 2 \\
\hline & & & $\mathrm{C} 5 \mathrm{C}^{2}$ & 005355 & 2 & C521 & 0.1605 & 1 \\
\hline & & & 0.52 & 0.0.5ग & 2 & C522 & 0.1065 & 2 \\
\hline & & & & & & C611 & 0.0585 & 2 \\
\hline & & & C61 & 0.05015 & 3 & C612 & 0.06825 & 1 \\
\hline & & & C62 & 0.0782 & 2 & C621 & 0.07875 & 2 \\
\hline $\mathrm{C} 6$ & 0,0418 & 6 & 02 & 0.0102 & 2 & C622 & 0.18825 & 1 \\
\hline 60 & 0.0418 & 0 & & & & C631 & 0.063 & 3 \\
\hline & & & & & & C632 & 0.05775 & 4 \\
\hline & & & $\mathrm{C} 63$ & 0.0969 & 1 & C633 & 0.11025 & 2 \\
\hline & & & & & & $\mathrm{C} 634$ & 0.057 & 5 \\
\hline & & & & & & C635 & 0.19875 & 1 \\
\hline & & & & & ? & $\mathrm{C} 711$ & 0.0375 & 2 \\
\hline & & & $\mathrm{C} 71$ & 0.1615 & 2 & $\mathrm{C} 712$ & 0.066 & 1 \\
\hline & & & & & & $\mathrm{C} 721$ & 0.054 & 3 \\
\hline $\mathrm{C} 7$ & 0.0722 & 4 & $\mathrm{C} 72$ & 0.2669 & 1 & $\mathrm{C} 722$ & 0.054 & 3 \\
\hline & & & $\mathrm{Cr} 2$ & 0.2669 & 1 & C723 & 0.05475 & 2 \\
\hline & & & & & & $\mathrm{C} 724$ & 0.126 & 1 \\
\hline & & & $\mathrm{C} 73$ & 0.0833 & 3 & & & \\
\hline & & & $\mathrm{C} 81$ & 0.17935 & 2 & C811 & 0.01875 & 4 \\
\hline & & & & & & C812 & 0.0285 & 3 \\
\hline & & & & & & C813 & 0.06525 & 2 \\
\hline & & & & & & C814 & 0.1545 & 1 \\
\hline $\mathrm{C} 8$ & 0.0494 & 5 & & & & C821 & 0.02775 & 3 \\
\hline & & & $\mathrm{C} 82$ & 00901 & 3 & $\mathrm{C} 822$ & 0.14475 & 1 \\
\hline & & & 082 & & 3 & C823 & 0.06975 & 2 \\
\hline & & & & & & C824 & 0.024 & 4 \\
\hline & & & $\mathrm{C} 83$ & 0.21165 & 1 & C831 & 0.105 & 2 \\
\hline & & & C83 & 0.21165 & 1 & $\mathrm{C} 832$ & 0.162 & 1 \\
\hline & & & C91 & 0.1105 & 2 & & & \\
\hline C9 & 0.0893 & 3 & C92 & 0.3094 & 1 & & & \\
\hline & & & C93 & 0.09265 & 3 & & & \\
\hline
\end{tabular}




\section{References}

1. Kimiagari, S., Keivanpour, S., Al-Azad, M.S. and Mohiuddin, M." Using the fuzzy delphi method to apply a model of knowledge transfer through international strategic alliances in upstream oil and gas sectors", Contemporary Management Research, 11(4), p. 409 (2015)

2. Hu, M.Y. and Chen, H. "An empirical analysis of factors explaining foreign joint venture performance in China”, Journal of Business Research, 35(2), pp. 165173 (1996).

3. Contractor, F.J. and Lorange, P. "The growth of alliances in the knowledge-based economy", International Business Review, 11(4), pp. 485-502 (2002).

4. Hitt, M.A., Dacin, M.T., Levitas, E., Arregle, J.L. and Borza, A. "Partner selection in emerging and developed market contexts: Resource-based and organizational learning perspectives", Academy of Management Journal, 43(3), pp. 449-467 (2000).

5. Lu, J.W. and Beamish, P.W. "Partnering strategies and performance of SMEs' international joint ventures", Journal of Business Venturing, 21(4), pp. 461486 (2006).

6. Aydogan, G. and Koksal, A. "An analysis of international construction risk factors on partner selection by applying ANP approach", Risk Management, pp. 658-669 (2014). (DOI: http://dx.doi.org/ 10.1061/9780784413135.062).

7. Hajidimitriou, Y.A. and Georgiou, A.C. "A goal programming model for partner selection decisions in international joint ventures", European Journal of Operational Research, 138(3), pp. 649-662 (2002).

8. Costa, R. and Evangelista, S. "An AHP approach to assess brand intangible assets", Measuring Business Excellence, 12(2), pp. 68-78 (2008).

9. Calabrese, A., Costa, R. and Menichini, T. "Using fuzzy AHP to manage intellectual capital assets: An application to the ICT service industry", Expert Systems with Applications, 40(9), pp. 3747-3755 (2013).

10. Leung, L.C. and Cao, D. "On consistency and ranking of alternatives in fuzzy AHP", European Journal of Operational Research, 124(1), pp. 102-113 (2000).

11. Kahraman, C., Cebeci, U. and Ruan, D. "Multiattribute comparison of catering service companies using fuzzy AHP: the case of Turkey", International Journal of Production Economics, 87(2), pp. 171-184 (2004).

12. Saaty, T.L., The Analytic Hierarchy Process, New York, McGraw-Hill (1980).

13. Kimiagari, S. and Dabbaghi, A. "Proposing a fuzzy multi attribute model to assess the security of supplying and transferring energy in Persian Gulf", 17th International Conference on Persian Gulf (stand point of juridical), Tehran-Iran (2007).
14. NPC Website: http://english.nipc.ir/

15. Caloghirou, Y., Ioannides, S. and Vonortas, N.S. "Research joint ventures", Journal of Economic Surveys, 17(4), pp. 541-570 (2003).

16. Child, J. and Yan, Y. "Predicting the performance of international joint ventures: an investigation in China", Journal of Management Studies, 40(2), pp. 283-320 (2003).

17. Demirbag, M. and Mirza, H. "Factors affecting international joint venture success: an empirical analysis of foreign-local partner relationships and performance in joint ventures in Turkey", International Business Review, 9(1), pp. 1-35 (2000).

18. Boateng, A. and Glaister, K.W. "Performance of international joint ventures: evidence for West Africa", International Business Review, 11(5), pp. 523-541 (2002).

19. Beamish, P. and Delios, A. "Improving joint venture performance through congruent measures of success", In Cooperative Strategies, European Perspectives, P. Beamish and P. Killing, Eds., San Francisco, CA, The Lexington Press, pp. 103-127 (1997).

20. Williamson, O.E., Markets and Hierarchies: Analysis and Antitrust Implications, New York, Free Press (1975).

21. Williamson, O.E., The Economic Institutions of Capitalism: Firms, Markets, Relational Contracting, New York, New York University Press (1985).

22. Beamish, P.W. and Banks, J.C. "Equity joint ventures and the theory of the multinational enterprise", Journal of International Business Studies, 18, pp. 1-16 (1987).

23. Hennart, J.-F. "A transaction costs theory of equity joint ventures", Strategic Management Journal, 9, pp. 361-374 (1988).

24. Buckley, P.J. and Casson, M., The Future of the Multinational Enterprise, 1, London, Macmillan (1976).

25. Harrigan, K.R., Managing for Joint Venture Success, Lexington, MA, Lexington Books (1986).

26. Porter, M.E. and Fuller, M.B. "Coalitions and global strategy", In Competition in Global Industries, M.E. Porter, Ed., Boston, MA, Harvard Business School Press, pp. 315-345 (1986).

27. Kogut, B. "A study of the life cycle of joint ventures", Management International Review, 28, pp. 39-52 (special issue) (1988b).

28. Kogut, B. "Joint ventures: Theoretical and empirical perspectives", Strategic Management Journal, 9, pp. 319-332 (1988a).

29. Lyles, M.A. "Learning among joint venture-sophisticated firms", Management International Review, 28, pp. 85-98 (special issue) (1988).

30. Ciborra, C. "Alliances as learning experiments: Cooperation, competition and change in high tech industries", In Strategic Partnership: States, Firms 
and International Competition, L.K. Mytelka, Ed., Rutherford, NJ, Farleigh Dickson University, pp. 5177 (1991).

31. Hamel, G. "Competition for competence and interpartner learning within international strategic alliances", Strategic Management Journal, 12, pp. 83103 (special issue) (1991).

32. Pfeffer, J. and Nowak, P. "Joint ventures and inter organizational interdependence", Administrative Science Quarterly, pp. 398-418 (1976).

33. Pfeffer, J. and Salancik, G.R., The External Control of Organizations: A Resource Dependence Perspective, New York, Harper and Row Publishers (1978).

34. Andersen, O. and Suat Kheam, L. "Resource-based theory and international growth strategies: an exploratory study", International Business Review, 7(2), pp. 163-184 (1998).

35. Blodgett, L.L. "Toward a resource-based theory of bargaining power in international joint ventures", Journal of Global Marketing, 5(1/2), pp. 35-54 (1991a).

36. Blodgett, L.L. "Partner contributions as predictors of equity share in international joint ventures", Journal of International Business Studies, 22(1), pp. 63-78 (1991b).

37. Kimiagari, S., Jolai, F. and Moazami, M. "Joint venture: An appropriate approach for durable development in Persian gulf area (security management)", 18th International Conference on Persian Gulf (Stand Point of Security), Tehran-Iran (2008).

38. Kimiagari, S. and Jolai, F. "Joint venture: The best tool for Iranian car manufacturing development", 2nd International Conference on Auto-part Manufacturing, Tehran-Iran (2007).

39. Beamish, P.W. "The characteristics of joint ventures in developed and developing countries", Columbia Journal of World Business, 20, pp. 13-19 (1985).

40. Merchant, H. and Schendel, D. "How do international joint ventures create shareholder value?", Strategic Management Journal, 21, pp. 723-737 (2000).

41. Ainuddin, R.A., Beamish, P.W., Hulland, J.S. and Rouse, M.J. "Resource attributes and firm performance in international joint ventures", Journal of World Business, 42(1), pp. 47-60 (2007).

42. Habib, G.M. "Measures of manifest conflict in international joint ventures", Academy of Management Journal, 30(4), pp. 808-816 (1987).

43. Inkpen, A.C., The Management of International Joint Ventures: An Organizational Learning Perspective, London, Routledge (1995).

44. Johnson, J.L., Cullen, J.B., Sakano, T. and Takenouchi, H. "Setting the stage for trust and strategic integration in Japanese-US cooperative alliances", Journal of International Business Studies, pp. 9811004 (1996).
45. Morris, M.W., Williams, K.Y., Leung, K. and Larrick, R.P. "Conflict management style: Accounting for cross-national differences", Journal of International Business Studies, 29, pp. 729-748 (1998).

46. Glaister, K.W. and Buckley, P.J. "Performance relationships in UK international alliances", Management International Review, 39, pp. 123-147 (1999).

47. Isobe, T., Makino, S. and Montgomery, D.B. "Resource commitment, entry timing and market performance of foreign direct investments in emerging economies: The case of Japanese international joint ventures in China", Academy of Management Journal, 43, pp. 468-484 (2000).

48. Inkpen, A.C. and Crossan, M.M. "Believing is seeing: Joint ventures and organizational learning", Journal of Management Studies, 32(5), pp. 596-618 (1995).

49. Lecraw, D.J. "Bargaining power, ownership and profitability of subsidiaries of TNCs in developing countries", Journal of International Business Studies, 15(1), pp. 27-43 (1984).

50. Gomes-Casseres, B. "Firm ownership preferences and host government restrictions: An integrated approach", Journal of International Business Studies, 21(1), pp. 1-22 (1990).

51. Bellman, R.E. and Zadeh, L.A. "Decision-making in a fuzzy environment", Management Science, 17(4), B141 (1970).

52. Ding, J.F. and Liang, G.S. "Using fuzzy MCDM to select partners of strategic alliances for liner shipping", Information Sciences, 173(1), pp. 197-225 (2005).

53. Ding, J.F. "Fuzzy MCDM approach for selecting strategic partner: An empirical study of a container shipping company in Taiwan", International Journal of Innovative Computing, Information and Control, 5(4), pp. 1055-1068 (2009).

54. Liou, J.J., Tzeng, G.H., Tsai, C.Y. and Hsu, C.C. "A hybrid ANP model in fuzzy environments for strategic alliance partner selection in the airline industry", Applied Soft Computing, 11(4), pp. 3515-3524 (2011).

55. Ma, Y.R. and Wang, X. "Partner selection model based on fuzzy language group decision-making method for dynamic logistics alliance under multiple time periods", Journal of Systems Engineering, 6, 007 (2008).

56. Yong, D.A.I. "AHP based DEA analysis on virtual logistics alliance partner selection", Journal of Systems Engineering, 3, 010 (2002).

57. Wang, T.C. and Chen, Y.H. "Applying consistent fuzzy preference relations to partnership selection", Omega, 35(4), pp. 384-388 (2007).

58. Lee, A.H. "A fuzzy supplier selection model with the consideration of benefits, opportunities, costs and risks", Expert Systems with Applications, 36(2), pp. 2879-2893 (2009).

59. Önüt, S., Kara, S.S. and Işik, E. "Long term supplier selection using a combined fuzzy MCDM approach: 
A case study for a telecommunication company", Expert Systems with Applications, 36(2), pp. 38873895 (2009).

60. Bevilacqua, M., Ciarapica, F.E. and Giacchetta, G. "A fuzzy-QFD approach to supplier selection", Journal of Purchasing and Supply Management, 12(1), pp. 14-27 (2006).

61. Yang, J.L., Chiu, H.N., Tzeng, G.H. and Yeh, R.H. "Vendor selection by integrated fuzzy MCDM techniques with independent and interdependent relationships", Information Sciences, 178(21), pp. 4166-4183 (2008).

62. Lin, C.W.R. and Chen, H.Y.S. "A fuzzy strategic alliance selection framework for supply chain partnering under limited evaluation resources", Computers in Industry, 55(2), pp. 159-179 (2004).

63. Chamodrakas, I., Batis, D. and Martakos, D. "Supplier selection in electronic marketplaces using satisficing and fuzzy AHP", Expert Systems with Applications, 37(1), pp. 490-498 (2010).

64. Mikhailov, L. "Fuzzy analytical approach to partnership selection in formation of virtual enterprises", Omega, 30(5), pp. 393-401 (2002).

65. Chan, F.T., Kumar, N., Tiwari, M.K., Lau, H.C.W. and Choy, K.L. "Global supplier selection: a fuzzyAHP approach", International Journal of Production Research, 46(14), pp. 3825-3857 (2008).

66. Wang, T.Y. and Yang, Y.H. "A fuzzy model for supplier selection in quantity discount environments", Expert Systems with Applications, 36(10), pp. 1217912187 (2009).

67. Büyüközkan, G., Çifçi, G. and Güleryüz, S. "Strategic analysis of healthcare service quality using fuzzy AHP methodology", Expert Systems with Applications, 38(8), pp. 9407-9424 (2011).

68. Vinodh, S., Anesh Ramiya, R. and Gautham, S.G. "Application of fuzzy analytic network process for supplier selection in a manufacturing organization", Expert Systems with Applications, 38(1), pp. 272-280 (2011).

69. Li, D. "A fuzzy multi-attribute decision-making method for partner selection of cooperation innovation alliance", In The 19th International Conference on Industrial Engineering and Engineering Management, pp. 9-17, Springer Berlin Heidelberg (2013).

70. Kannan, D., Khodaverdi, R., Olfat, L., Jafarian, A. and Diabat, A. "Integrated fuzzy multi-criteria decision making method and multi-objective programming approach for supplier selection and order allocation in a green supply chain", Journal of Cleaner Production, 47, pp. 355-367 (2013).

71. Wu, C. and Barnes, D. "A literature review of decisionmaking models and approaches for partner selection in agile supply chains", Journal of Purchasing and Supply Management, 17(4), pp. 256-274 (2011).
72. Lima Junior, F.R., Osiro, L. and Carpinetti, L.C.R. "A comparison between fuzzy AHP and fuzzy TOPSIS methods to supplier selection", Applied Soft Computing, 21, pp. 194-209 (2014).

73. Bodily, S.E. "Note-A. Delegation process for combining individual utility functions", Management Science, 25(10), pp. 1035-1041 (1979).

74. Xu, Z. "Group decision making based on multiple types of linguistic preference relations", Information Sciences, 178(2), pp. 452-467 (2008).

75. Yue, Z. "A method for group decision-making based on determining weights of decision makers using TOPSIS", Applied Mathematical Modelling, 35(4), pp. 1926-1936 (2011).

76. Yue, Z. "Developing a straightforward approach for group decision making based on determining weights of decision-makers", Applied Mathematical Modelling, 36(9), pp. 4106-4117 (2012).

77. Subramanian, N. and Ramanathan, R. "A review of applications of analytic hierarchy process in operations management", International Journal of Production Economics, 138(2), pp. 215-241 (2012).

78. Keivanpour, S., Haleh, H. and Ganjavi, H.S. "A decision model for selecting the optimum oil production profile using multi criteria decision making and social choice theory", In ASME 2014 International Mechanical Engineering Congress and Exposition, American Society of Mechanical Engineers (2014).

79. Dubois, D. and Prade, H. "Operations on fuzzy numbers", International Journal of Systems Science, 9(6), pp. 613-626 (1978).

80. Dehghan, M. and Hashemi, B. "Solution of the fully fuzzy linear systems using the decomposition procedure", Applied Mathematics and Computation, 182(2), pp. 1568-1580 (2006).

81. Zadeh, L.A. "Fuzzy sets", Information and control, 8(3), pp. 338-353 (1965).

82. Buckley, J.J. "Fuzzy hierarchical analysis", Fuzzy Sets and Systems, 17(3), pp. 233-247 (1985).

83. Wang, Y.M. and Elhag, T. "On the normalization of interval and fuzzy weights", Fuzzy Sets and Systems, 157(18), pp. 2456-2471 (2006).

84. Wang, Z.X., Liu, Y.J., Fan, Z.P. and Feng, B. "Ranking LR fuzzy number based on deviation degree", Information Sciences, 179(13), pp. 2070-2077 (2009).

85. Khoshrou, S. "The petrochemical industry in Iran naft, gaz, petroshimi", Monthly Magazine, 21, pp. 1-6 (Aug. 2003).

86. Choo, E.U. and Wedley, W.C. "Comparing fundamentals of additive and multiplicative aggregation in ratio scale multi-criteria decision making", The Open Operational Research Journal, 2, pp. 1-7 (2008).

87. Kimiagari, A.M., Jasemi, M. and Kimiagari, S. "A modern neural network model to do stock market timing on the basis of the ancient investment technique of Japanese candlestick", In Proceedings of the 21st 
IASTED International Conference, 696(083), p. 165 (2010).

88. Iranmanesh, H., Mojir, N. and Kimiagari, S. "A new formula to "Estimate at completion" of a Project's time to improve "Earned value management system"", In Industrial Engineering and Engineering Management, 2007 IEEE International Conference on (pp. 1014-1017), IEEE (December, 2007).

89. Kimiagari, S., Keivanpour, S., Mohiuddin, M. and Van Horne, C. "The cooperation complexity rainbow: challenges of stakeholder involvement in managing multinational firms", International Journal of Business and Management, 8(22), pp. 50-64 (2013).

90. Kimiagari, S., Gabrielsson, P., Gabrielsson, M. and Montreuil, B. "5. Market strategy of international new ventures originating from a small and open economy", Handbook of Research on International Entrepreneurship Strategy: Improving SME Performance Globally, p. 85 (2015).

\section{Biographies}

Salman Kimiagari is Assistant Professor at School of Business and Economics in Thomson River University. He earned his PhD from Business School of Laval University, MBA (Operation Management) from Industrial Engineering Department of the College of Engineering of the University of Tehran and Bachelor's degree in Operation Management from Faculty of Management of University of Tehran. His research activities are focused on strategic management, international business, business design, international marketing, and operation research.

Samira Keivanpour is a Post-Doctoral researcher in Mechanical Engineering Department of Faculty of Science and Engineering of Laval University, Canada. She earned her PhD degree in Industrial Engineering from Laval University, MBA in Operation Management and Bachelor's degree in Electrical Engineering from Iran. Her research activities are focused on green supply chain design, sustainable development, and design for environment, reverse logistics, and product's End of Life challenges.

Fariborz Jolai is a Professor of Industrial Engineering in the College of Engineering at the University of Tehran, Iran. He obtained his PhD degree in Industrial Engineering from INPG, Grenoble, France, in 1998. His current research interests are scheduling and production planning, supply chain modeling, optimization problems under uncertainty conditions.

Mansour Moazemi is a Professor in Petroleum University of Technology, Iran. He obtained his $\mathrm{PhD}$ degree in international business from Iran. He earned his master in industrial engineering from Amirkabir University of Technology and his Bachelor's degree in chemistry from Isfahan University. His research interests are strategic management, human resources, and energy. 